\title{
Interview with Prof. Abraham Nudelman - 2019 Honorable Member of the ICS
}

https://doi.org/10.51167/ice00007

\section{Arlene D. Wilson-Gordon}

Department of Chemistry, Bar-llan University, Ramat Gan 5290002

Email: gordon@biu.ac.il

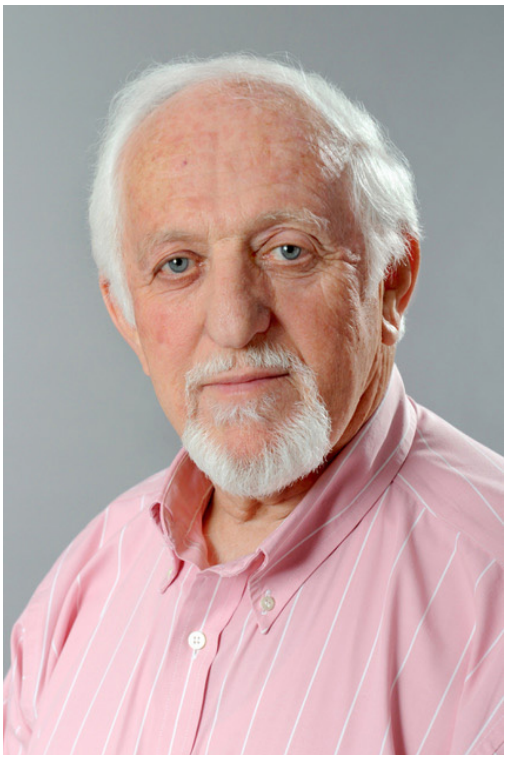

Q: Tell me a little about your personal history.

A: I was born in Mexico and came to Bar-Ilan University in 1957 as an undergraduate after finishing high school. After graduation from Bar-Ilan, I went to Brooklyn College in NY where I received an MSc degree in chemistry under the direction of Prof. Paul Haberfield in 1964. From Brooklyn College, I went to UCLA and got a PhD in chemistry in 1969 under the direction of Nobel Prize Laureate Prof. Donald Cram. Upon graduation I joined the pharmaceutical company
Wyeth Laboratories in Pennsylvania and worked there till 1975 when my family and I returned to Israel. I then worked for six years at the Weizmann Institute of Science and subsequently joined the Chemistry Department of Bar-Ilan University where I established the Division of Medicinal Chemistry, unique to Bar-Ilan. I worked in Bar-Ilan from 1981 reaching the rank of full professor and retired in 2008. My lab in Bar-Ilan is still functioning and I continue together with my assistants in my investigations in various fields of medicinal chemistry and drug development.

Q: What inspired you to study chemistry?

A: I had a good chemistry teacher in high school and a cousin of mine inspired me to pursue chemistry since he himself was a chemist and worked in the pharmaceutical company Syntex, first in Mexico and then in San Francisco.

Q: What attracted you to an academic career?

A: After working in industry for six years and as an investigator for another six years and considering that I had taught medicinal chemistry courses at the Weizmann Institute, I decided it was time for a change and that led me to an academic position at Bar-Ilan University.

Q: Who were your role models?

A: Prof. Donald Cram of course. I much admired Prof. Gilbert Stork's work at Columbia University and that of Dr. Herschel Smith, the Director of Research at Wyeth Labs., who

Arlene Wilson-Gordon was born in Glasgow, Scotland. She completed her BSc (Hons) at Glasgow University and her DPhil at Oxford University under the supervision of Peter Atkins. After a postdoc at the Hebrew University with Raphy Levine, she joined the faculty at the Department of Chemistry, Bar- Ilan University, where she rose to the rank of Professor and in 2015, Professor Emerita. Her research interests lie in the field of theoretical quantum and nonlinear optics. She is the editor of the Israel Chemist and Engineer, an online magazine for all who are interested in chemistry and chemical engineering.

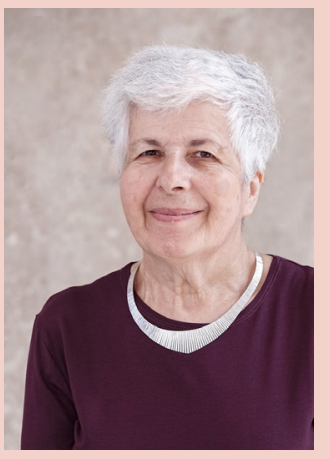


discovered the oral contraceptive Ovral - Norgestrel, which became the most popular contraceptive in the world. I have to mention also Prof. Shmuel Sprecher who was my main chemistry teacher at Bar-Ilan and taught me General and Inorganic Chemistry, Organic Chemistry and Mechanisms in Organic Chemistry.

Q: Why did you choose your particular field of research? A: I had worked at Wyeth Laboratories in a variety of areas of medicinal chemistry and was inspired by the beauty of the organic chemistry needed for the synthesis of new biologically active molecules, so the field of medicinal chemistry was an obvious area of research.

Q: Do you enjoy teaching and interacting with students? A: Most definitely, I thoroughly enjoy teaching and delight when I see a student's smile after understanding a complicated feature of the material.

Q: Do you have former students whose achievements you admire?

A: I have been fortunate that a considerable number of my former MSc and PhD students have reached good positions in a variety of fields in industry and research institutions. These include Lilach Hedvati who served as head of the generic drug synthesis at Teva Pharmaceuticals; Shani Zeeli a patent attorney; Dana Mizrachi who holds a senior position at the Biological Institute of Nes Ziona; Ayelet Nudelman, my former student and present daughter-in-law, who is a senior analytical chemist at Analyst Research Laboratories; Michal Weitman Head of the Mass Spectrum unit at BarIlan; Bilha Fischer and Amnon Albeck who are medicinal chemistry professors at Bar-Ilan - Amnon is now Rector and Bilha is Dean of Exact Sciences; Dvir Doron associate director of chemical and computational toxicology at Teva Pharmaceuticals; and Inessa Yanovski who is a researcher in the Chemistry Department of Bar-Ilan.

Q: What were the main difficulties you encountered in your research and how did you overcome them?

A: With the exception of a few highly unpleasant characters whom I encountered, I was lucky to be able to conduct my investigations in a generally pleasant manner, collaborating with good scientists both in Israel as well as abroad. This work led to the discovery of a significant number of biologically active substances in areas of cancer, bacteriology, schizophrenia, analgesia, sickle-cell anemia, inflammation, AIDS and others.

Q: What do you consider your greatest scientific achievement, so far?

A: Three of my compounds reached the stage of human clinical trials. The compounds labeled AN-9 as an anticancer agent, $\mathrm{AN}-10$ as a substance that increased fetal hemoglobin and AN-168 as an antischizophrenic drug. Presently, I am collaborating with Israel Prize Laureate, Prof. Marta Rosin, from the Hebrew University and we have discovered a family of extremely potent anti-inflammatory agents which have been patented and are at the preclinical stage. Another active collaboration is with Dr. Betty Pace from the Augusta University in Georgia, USA, where we are evaluating one of my compounds for the treatment of sickle-cell anemia.

In the course of my student Yaakov Herzing's PhD studies, we discovered a new chemical reaction that we applied to a novel patentable procedure for the synthesis of the anticancer agent Etoposide. Based on this synthetic method, Teva Pharmaceuticals developed an industrial process for the synthesis of Etoposide and marketed the compound for many years.

In addition, I came up with the idea of creating a list of the $\mathrm{H}^{1}$ and $\mathrm{C}^{13}$ NMR chemical shifts of common solvents. In collaboration with Dr. Hugo Gottlieb, this work was published as "NMR chemical shifts of common laboratory solvents as trace impurities" in the Journal of Organic Chemistry in 1997. This article has become the MOST READ article in the history of the Journal of Organic Chemistry with close to 660,000 "reads". It has been cited thousands of times and to the best of my understanding has been printed innumerable times by chemists worldwide who use the table most frequently, and has been incorporated into the catalogs of manufacturers of NMR equipment. Subsequently, in collaboration with investigators from Washington University and Caltech, a second publication entitled "NMR chemical shifts of trace impurities: Common laboratory solvents, organics, and gases in deuterated solvents relevant to the organometallic chemist" appeared in the journal Organometallics in 2010, which combined the data of our first publication with similar data related to solvents used in organometallic NMR studies. This publication also become the MOST READ in Organometallics, and both publications combined have become "Most Read" more than 1,100,000 times. The story of this original idea was further advanced when we were approached by investigators from Smith-Kline-Beacham Pharmaceuticals and published with them the third paper in the series, entitled "Development of GSK's NMR Guides - A tool to encourage the use of more sustainable solvents", in Green Chemistry in 2016, this time including NMR spectra of particular solvents used in industry and "green" solvents.

Q: What do you consider to be your greatest contribution to Israeli society?

A: I have been fortunate to be able to advise a good number of students who eventually became very successful and continue to serve society in a highly positive manner. 


\section{העתיד של ניטור חדרים

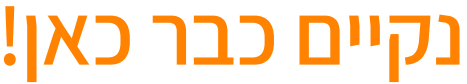

כל היתרונות במכשיר אחד

הכירו את מכשיך +MET ONE 3400 החדש והמתקדם ביותר.

מפה נטענת והגדרת שיטות דיגום

בקרה אלקטרונית של גרסאות שיטות הדיגום

בדיקה ואישור לאחר השלמת הדיגום

חתימות אלקטרוניות

תוכנה ידידותית וקלה לתפעול

\section{מבצע לרגל השקת המכשיר החדש}

50\% הנחה על שנת הכיול השניה

(שנת הכיול הראשונה ללא תשלום) הכיול השניה

IX

\section{קבלת מזוודה מקורית לנשיאת המכשיר}

ללא עלות נוספת לה לניאת

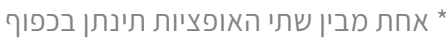

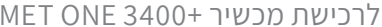

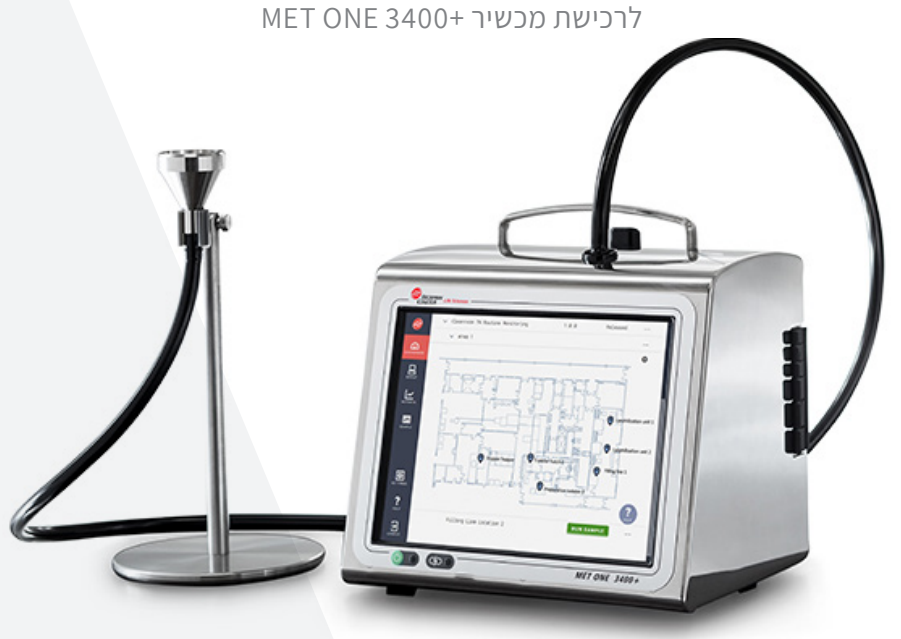

לפרטים נוספים, אינה גלוזגל:

054-490-6139

inna@rhenium.co.il
Q: Would you recommend a scientific career to young people? A: Yes, provided they have a lot of stamina and patience, and the ability to interact with students, staff, university bureaucracy and granting institutions.

Q: If you had a magic wand, what would you change a) in academic life, b) in Israeli society?

A: In Israeli society, I would change the way people and parties are elected to the Knesset. If I could, I would attempt to reduce inequality in education, army service and salaries. I would love to reduce the extremes, both from religious as well as political positions. I dream I could see people who are wellbehaved, clean, not pushy, considerate of their surroundings.

Q: Do you have any advice for young people embarking on their career?

A: Try to get involved in something that really interests you. Expect to encounter all types of people in your career, from intelligent, cooperative and pleasant to jealous, miserable, lazy and incompetent characters. Try to keep up your best standards but at times be willing to compromise.

Q: Do you have any hobbies or interests apart from your scientific work?

A: I love Spanish poetry, classical music and geography. 